\title{
Assessment of the Effectiveness of Potassium Polyacrylate on Crop Production
}

\author{
Yélézouomin Stéphane Corentin Somé1,2, Diakalya Traoréé ${ }^{2 *}$ Malicki Zoromé ${ }^{3}$, \\ Pounyala Awa Ouoba², Dapola Evariste Constant $\mathrm{Da}^{2}$
}

\author{
${ }^{1}$ Université Norbert ZONGO de Koudougou, Lettres des Sciences Humaines (LSH), Géographie/Laboratoire de Recherche en \\ Sciences Humaines (LABOSH), 01 BP 6820 Ouagadougou 01, Burkina Faso \\ ${ }^{2}$ Université Joseph KI-ZERBO, Sciences Humaines (SH), Géographie/Laboratoire Dynamique des Espaces et Sociétés (LDES), \\ Burkina Faso, 03 BP 7021 Ouagadougou 03, Burkina Faso \\ ${ }^{3}$ Institut International d'Ingénierie de l'eau et de l'Environnement, BP 594 Ouagadougou 01, Burkina Faso \\ Email: Some_y@yahoo.fr, ziediakalyatraore@gmail.com, *ziediakalyatraore@gmail.com, \\ zoromemalick@yahoo.fr,mpounyala@gmail.com,dadapola432@gmail.com
}

How to cite this paper: Somé, Y.S.C Traoré, D., Zoromé, M., Ouoba, P.A. and Da, D.E.C. (2021) Assessment of the Effectiveness of Potassium Polyacrylate on Crop Production. Journal of Agricultural Chemistry and Environment, 10, 113-123.

https://doi.org/10.4236/jacen.2021.101008

Received: January 13, 2021

Accepted: February 23, 2021

Published: February 26, 2021

Copyright (c) 2021 by author(s) and Scientific Research Publishing Inc. This work is licensed under the Creative Commons Attribution International License (CC BY 4.0).

http://creativecommons.org/licenses/by/4.0/

\begin{abstract}
Water control is a major problem in crop production, particularly in fragile ecosystems such as the Sahel. Water is the most important factor in plant productivity. Many initiatives have been developed in this direction, including all methods of irrigation and water and soil conservation. The objective of this work is to assess the effectiveness of this amendment in crop production in the context of climate variability. The methodology is based on experimentation to statistically compare the natural biomass on a soil of silty-clay-sandy texture, divided into two blocks, one of which is amended with potassium polyacrylate and the other is not. This study showed that the wet and dry biomasses produced on soils with potassium polyacrylate are significantly higher than those produced on unamended soils at the $5 \%$ threshold. Based on these results, potassium polyacrylate may be a solution to recurrent dryness pockets. However, uncontrolled environmental testing is necessary to confirm these results.
\end{abstract}

\section{Keywords}

Water Management, Plant Production, Potassium Polyacrylate, Ouagadougou

\section{Introduction}

The Sahel region of West Africa has long been known for the occurrence of severe and widespread drought. The analysis of this drought was accentuated on the basis of studies by [1] [2] [3] because it was of interest to climatologists, hy- 
drologists, ecologists and atmospheric dynamists [4]. The main objectives of this work have been to identify and assess the effects of successive droughts on ecosystems, hydrological regimes and human activities over time. Three episodes were then identified. These were 1911-1913, 1940-1943 and 1968-1990 [3] [5]. The last episode is undoubtedly the most documented, as direct measurements of climatic factors in West Africa began in the middle of the 19th century [5]. Furthermore, studies have shown that since the late 1960s and early 1970s, rainfall has not only declined considerably but has also been characterized by interannual and monthly variations. Drought is a manifestation of rainfall variability [6]. This rainfall deficit has had significant negative impacts on water resources, agriculture and livestock, which are key sectors of the economy in several African countries [5] [6] [7] [8]. For [9], "drought spells impact both surface and groundwater resources and they can lead to reductions in water supply, crop failure, as well as a host of other associated economic and social activities p.1". This situation is further complicated by the fact that a large part of the Sahelian population depends on rain-fed agriculture [10], even though agricultural yields have fallen considerably since 1970 [11]. The fall in agricultural production is correlated with the strong climatic variation experienced in West Africa, especially in the Sahelian region during the 1970s [11]. In Burkina Faso, the combined effects of low rainfall and higher temperatures cause increased evaporation, degrade soils, contribute to the spread of harmful species, reduce agricultural yields and destroy biodiversity [12]. In addition to climatic variations, water deficiency is due to anthropogenic factor and rapid population growth which reduced the availability of water and land per capita [12]. That is why, Richardson, et al., 2009 in [13] conclude that "given the considerable uncertainties around projections of climate impacts on water resources at local and regional scales, building resilience, managing risks, and employing adaptive management are likely to be the most effective adaptation strategies". These multiple consequences lead farmers to develop strategies to respond and adapt to new climatic conditions. This article is part of the research on strategies for adapting to climate variability. It experiments with solid water, also known as potassium polyacrylate, a product capable of compensating for the water deficit linked to the effects of pockets of drought on plant production. What are the effects of potassium polyacrylate on the production of herbaceous biomass? The aim of this study is to understand the evolution of herbaceous plants on the experimental plots and to evaluate the impact of potassium polyacrylate on the production of herbaceous biomass in Ouagadougou.

\section{Methodology}

\subsection{Study Area}

Located between $12^{\circ} 18^{\prime}$ and $12^{\circ} 28^{\prime}$ north latitude and $1^{\circ} 26^{\prime}$ and $1^{\circ} 37^{\prime}$ west longitude, Ouagadougou is the capital of the province of Kadiogo and the Central Region (Figure 1). 


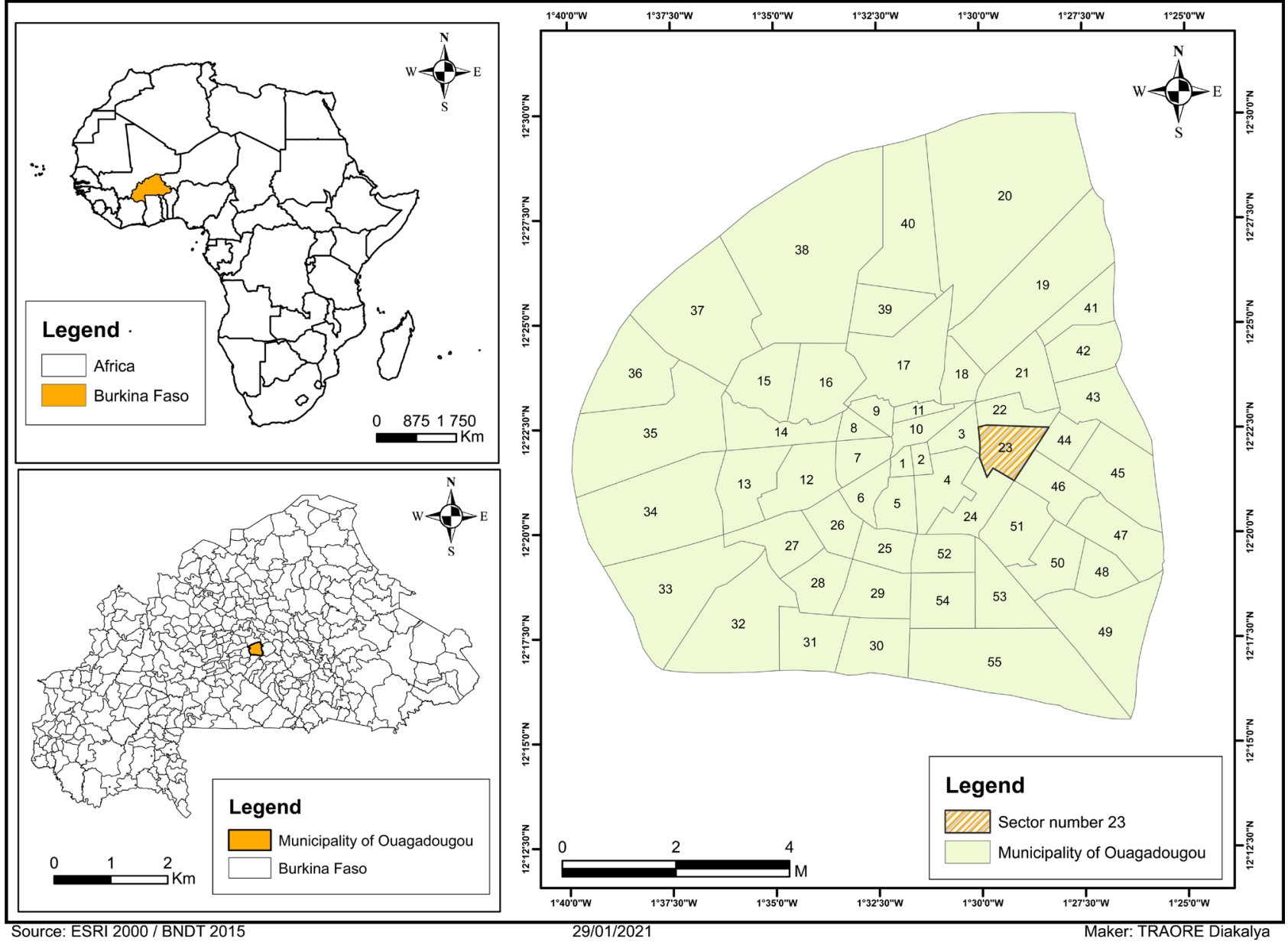

Figure 1. Study area.

Ouagadougou is located in the Sudan-Sahelian zone and is characterized by a tropical climate with two main seasons: a rainy season and a dry season. The first is marked by wet monsoon winds and extends from May to October. The rainwater heights are about $700 \mathrm{~mm}$. The so-called dry one runs from October to May is dominated by the harmattan winds. Temperatures range from $22^{\circ} \mathrm{C}$ to $35^{\circ} \mathrm{C}$, giving a thermal amplitude of $28.5^{\circ} \mathrm{C}$.

\subsection{Device, Methods and Materials}

The Standardized Precipitation Index was used to characterize the severity of the drought. It is divided into 5 classes and was inspired by the works of [4] [15] [16] [17] [18] [19]. It answers the following formula: $S P I=\frac{\left(X_{i}-X_{m}\right)}{S_{i}}$, where, $X_{i}$ represents the rainfall cumulation of year $i ; X_{m}$ and $S_{i}$ are respectively the mean and standard deviation of the rains for the series studied, by 1977 to 2017.

For the purposes of the study, the experimental device set up consists of two trials with 12 repetitions each, for a total of 24 repetitions (Figure 2). The first test contains approximately $0.9 \mathrm{~m}^{3}$ of soil with $40 \mathrm{~g}$ of hydrated granulated solid water or 201 of solid water. The second test is identical to the first test, except 
that it does not contain solid water (Figure 2).

Potassium polyacrylate is a water retention agent. It can increase the availability of moisture to plants. It mixes with the soil to increase the ability of the soil to retain water, in the form of water gel that stays in the soil for a few months and to make it available to plants. This improved soil easily releases moisture, as well as water-soluble nutrients, to plant roots on demand. Potassium polyacrylate works like a sponge under the soil surface. It is composed of a set of polymer chains, which are chemically bound to become an insoluble matrix in water, similar to a network, which gently attracts and retains hydrogen molecules. The immense size and weight of its molecular structure allow each potassium polyacrylate granule to absorb more than 500 times its initial weight in purified water [14] [15] [16].

Soil samples were collected and physico-chemical analyses were carried out at BUNASOL in Burkina Faso. For the determination of potassium polyacrylate and the weighing of biomass, the harvesting and drying of the phytomass, the material consisting of a balance, a secateurs, bags and ovens were used respectively. For the assessment of the weight differential between wet biomass and dry biomass, the Wilcoxon non-parametric statistical test was used.

\subsection{Definition and Determination of Herbaceous Biomass}

According to DUVIGNAUD A. (1974) cited by SAVADOGO I. (2011), plant mass or biomass is the weight per unit area, expressed as dry matter, of the total living and dead matter of plants. This author specifies that a distinction must be made between the biomass itself which is equivalent to the living parts and the necropolis composed of the dead parts. Production, on the other hand, refers to the quantity of plant material per unit area and productivity corresponds to plant material per unit area and per unit time. The estimate of the phytomass or epigeal biomass of the herbaceous plants was made using the method of the

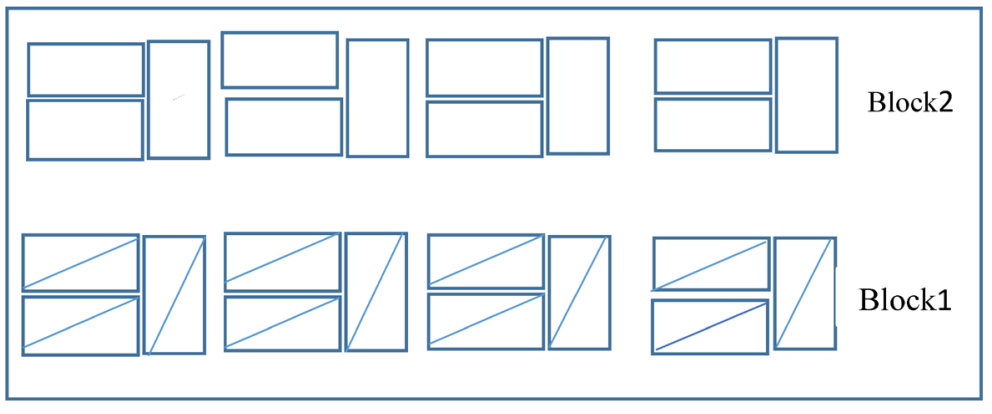

Block1 : ensemble des répétitions traitées

Block2 : ensemble des répétitions témoins

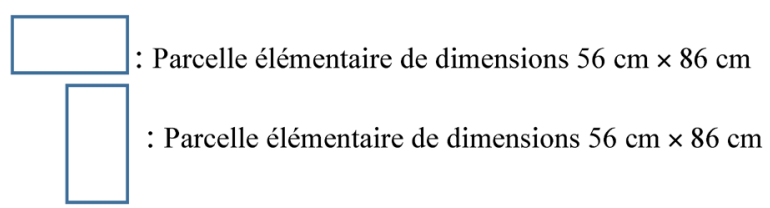

Figure 2. Experimental device. 
integral harvest on unit areas of $0.5 \mathrm{~m}^{2}$ in August, month during which the vegetation is at its maximum of epilation. This moment corresponded to the flowering and the beginning of the fructification. Wet biomass was determined immediately after harvest and dry biomass was carried out in the laboratory on samples of $500 \mathrm{~g}$ put in the oven at $85^{\circ} \mathrm{C}$ until obtaining constituent weight (LEVANG P. and GROUZIS M., 1980; FOURNIER A., 1982; YAMEOGO G., et al., 2013). The weight was increased every seventy-two (72) hours.

\section{Results and Discussion}

\subsection{Ouagadougou Rainfall Characterization by SPI from 1977 to 2017}

Rainfall varies from year to year [14] and is also characterized by a monthly irregularity. This rainfall variation was highlighted by the Standardized Precipitation Index. This index makes it possible to determine the dry years and the so-called wet years [15]. Thus, over a 41-year series, from 1977 to 2017, the SPI was calculated and represented in Figure 3. Rainfall, across the graph, is characterized by a drought period ranging from 1977 to 1990 and a wet phase from 1990 to 2017. On the other hand, a few years of the first period are punctuated by wet years and the second by dry years.

The results obtained are similar to those of [3] [4] [14] [15] [16], which attest that West Africa, particularly the Sahel, was the scene of a globalizing drought in the 1970s and 1980s. As for the wet period, its beginning is variously appreciated. For [4], it started around 1990 while it starts for [14] from 2003. In order to characterize the intensity of the drought, the Standardized Precipitation Index was divided into five classes of various degrees (Table 1).

This variable nature of rainfall has been the subject of several studies. Some authors are interested in the causes, others in the consequences of drought especially

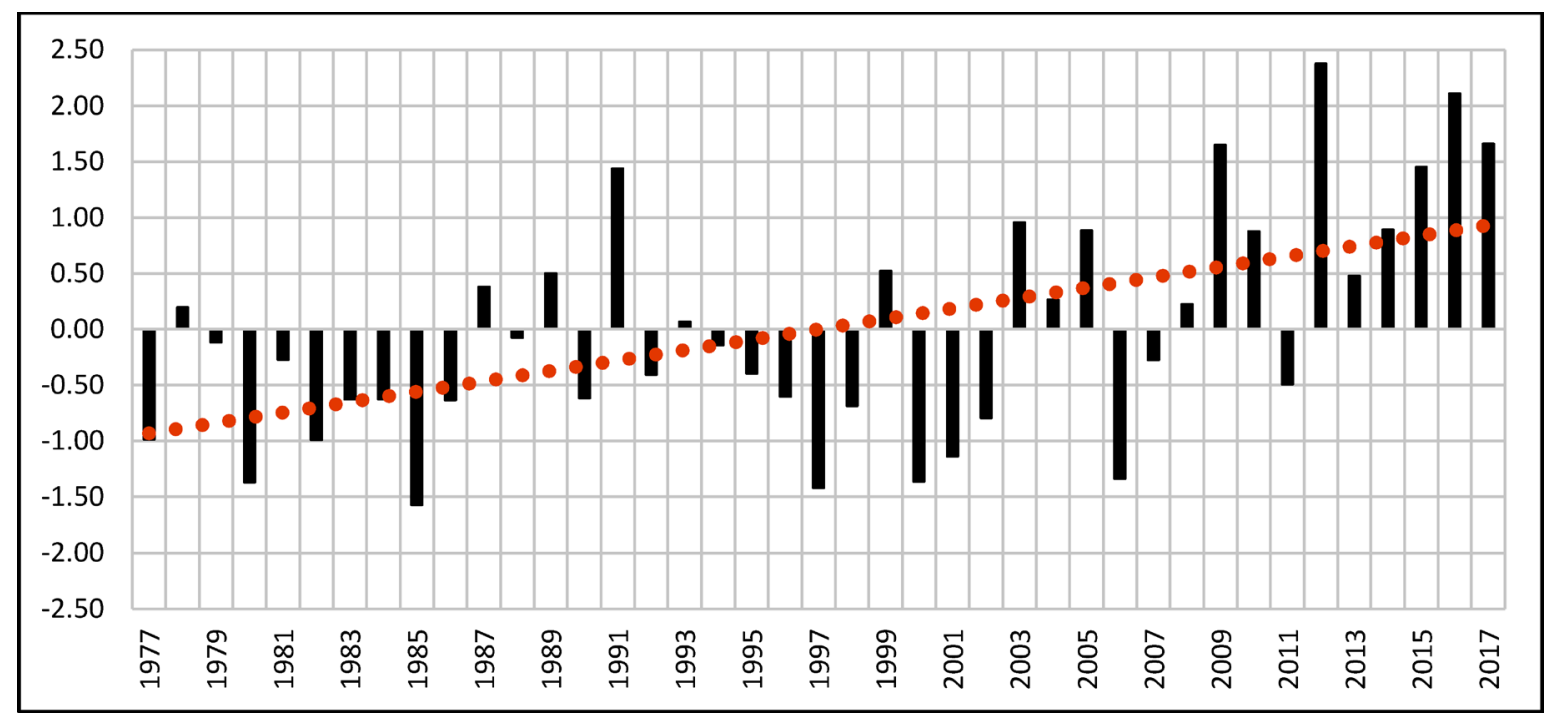

Source: Based on ANAM data, 2018.

Figure 3. Evolution of the Ouagadougou standardised precipitation index 1977-2017. 
from 1970 [4] [9] [10] [11] [17] [18] [19]. Water deficit is identified by [20] as a natural risk with complex impacts that impact water resources, agriculture and natural ecosystems. It had an impact on the capacity of groundwater to fill up [14] [21] [22].

\subsection{Physico-Chimical Characterizes}

The results of the contents of different part analysis are $27.45 \%$ clay; $23.53 \%$ silt and $49.02 \%$ sand. These results were presented in a triangle of textures. The textural triangle is a diagram used to define the texture of a soil (Figure 4). The 3 edges of the triangle are staggered from 0 to $100 \%$ and each represent a content part fraction (clay, silt and sand). The junction of these 3 different fractions in the diagram is used to determine the textural class of the soil. Thus, the soil used is a silty-clay-sandy texture with a water $\mathrm{PH}(\mathrm{W} / \mathrm{V}: 1 / 2.5)$ of 5.63 . Physical and chemical results are summarized in Table 2.

Table 1. Drought classification with standardized precipitations index.

\begin{tabular}{ccc}
\hline SPI classes & Degree of drought & Concerned year \\
\hline SPI $>2$ & Extreme humidity & 2012,2016 \\
$1<$ SPI $<2$ & Hight humidity & $2017,2009,2015,1991$ \\
$0<$ SPI $<1$ & Moderate humidity & $2003,2014,2005,2010,1999,1989,2013,1987$, \\
& & $2004,2008,1978,1993$ \\
$0<$ SPI $<-1$ & Moderate drought & $1988,1979,1994,1981,2007,1995,1992,2011$, \\
$-1<$ SPI $<-2$ & Severe drought & $1996,1990,1983,1984,1986,1998,2002,1977,1982$ \\
SPI $<-2$ & Extreme drought & $2001,2006,2000,1980,1997,1985$ \\
\end{tabular}

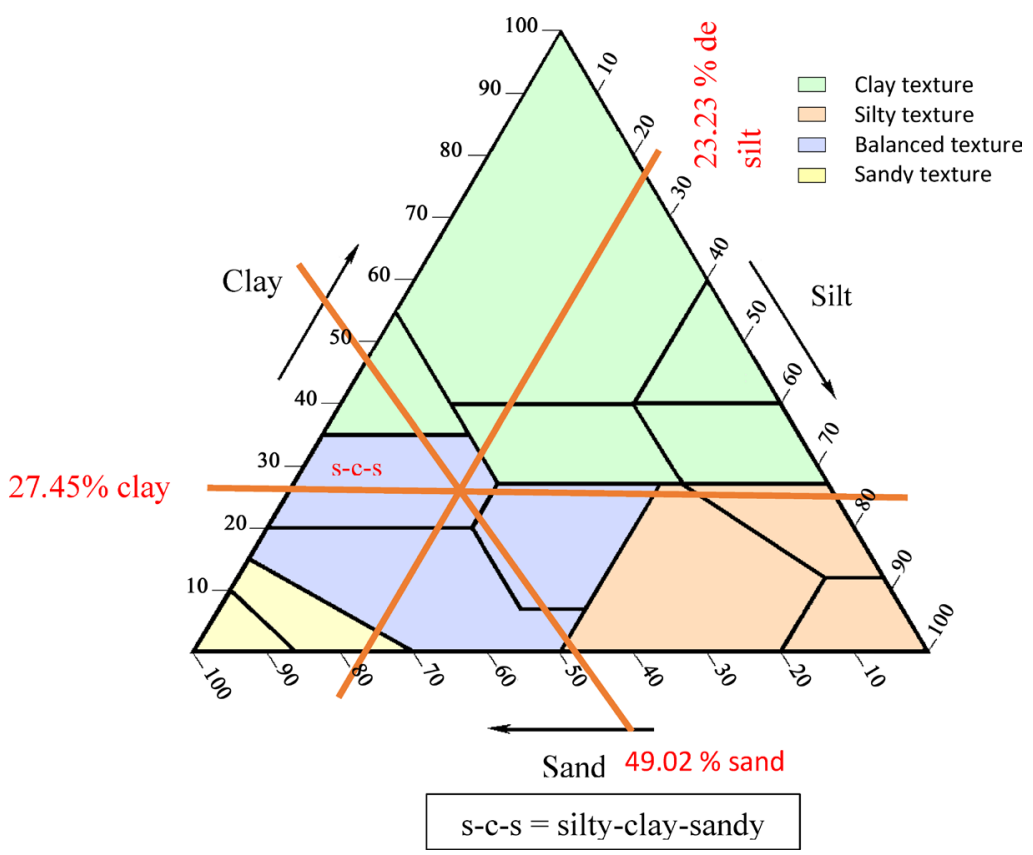

Figure 4. Texture triangle. 


\subsection{Germination of Herbaceous Plants}

Analysis of the germination rates of spontaneous species in the replicates showed significantly different results. Germination on Block 2 was completed from the ninth day after the start of the shoots and the thirteenth day after experimental device was installed with a daily average of $12.5 \%$. In fact, the germination is began the fifth day after installation of the device. At Block 1, germination was spread over 16 days with an average daily rate of $6.25 \%$ (Figure 5).

\subsection{Herbaceous Growth}

Weekly height measurements of the species Amaranthus graecizans Silvestris (Vill.) Brenan, 1961] have shown that this species evolves by about $88 \mathrm{~cm} /$ week or $13 \mathrm{~cm} /$ day on the treated block against a weekly average of $64 \mathrm{~cm}$ or 9 $\mathrm{cm} /$ week for controls (Figure 6). These measures were taken for 57 days. They

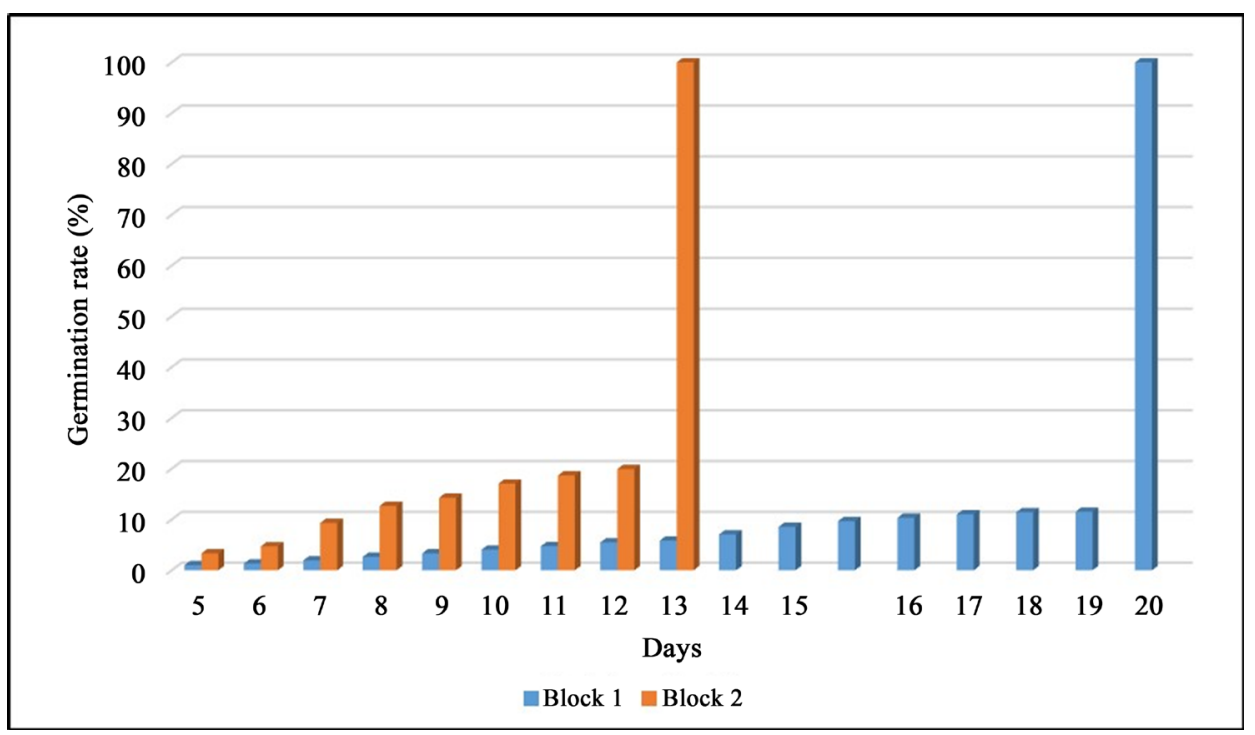

Figure 5. Germination of herbaceous plants in trials.

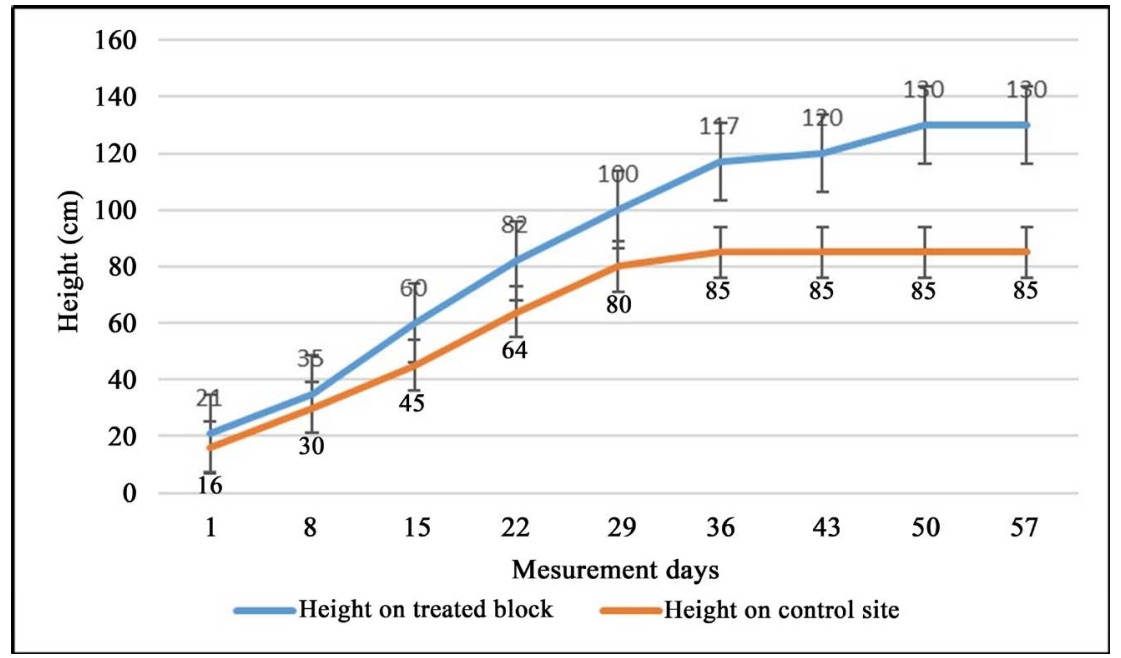

Figure 6. Weekly growth of Amaranthus graecizans. 
were suspended when the same values were obtained for the last two measurements. For example, for treated bins, the measurements were $130 \mathrm{~cm}$ in week eight and $130 \mathrm{~cm}$ in week nine. This shows that the individuals have reached their maximum mean size. Measurements on other species also showed this stabilization of growth and size differences between treated and untreated blocs.

\subsection{Herbaceous Spiked Phytomass or Herbaceous Biomass}

Examination of the results obtained shows that production is higher on the treated block than the untreated block. The production of wet biomass is estimated at 22,058 kilograms $(\mathrm{kg})$ of wet matter $(\mathrm{MH})$ over the $6 \mathrm{~m}^{2}$ during the four months of the experiment: $4 \mathrm{~kg} / \mathrm{MH} / \mathrm{m}^{2}$ and $7846 \mathrm{~kg}$ of dry matter (DM) or $1.5 \mathrm{~kg} / \mathrm{DM} / \mathrm{m}^{2}$ for the same area and for the same period. In addition, under the same conditions, we obtained a wet and dry biomass of $18.769 \mathrm{~kg}$ or $3 \mathrm{~kg} / \mathrm{MH} / \mathrm{m}^{2}$ and $6.76 \mathrm{~kg}$ or $1 \mathrm{~kg} / \mathrm{MS} / \mathrm{m}^{2}$ respectively for the controls. There is then a difference of $1 \mathrm{~kg} / \mathrm{MH} / \mathrm{m}^{2}$ and $0.5 \mathrm{~kg} / \mathrm{MS} / \mathrm{m}^{2}$ respectively between the wet and dry biomass of the treated and control plots. To verify this differential the Wilcoxon nonparametric statistical test was used.

\subsection{Matched Wilcoxon Test Results}

By applying the Wilcoxon test, the objective was to demonstrate that the data collected on the treated plots are significantly different from those of the control plots by their biomass. In this respect, the following hypotheses have been formulated:

H0: the biomass of the treated and control plots is identical.

$\mathrm{H} 1$ : the biomass of the treated and control plots is different.

Based on the results recorded in Table 3, all values are below the $\alpha$ threshold (5\%). At risk $\alpha$ of $5 \%$, we validate our initial hypothesis $\mathrm{H} 1$ and we can affirm that the biomass of the treated plots is significantly different from those of the controls. This implies that the null hypothesis (H0) is rejected.

\section{Conclusions}

This experimental study, which has been carried out in Ouagadougou, Burkina Faso, shows that solid water has a positive impact on plant productivity. The biomass and growth of Amarnathus graecizans from the treated replicates are significantly different from those of the controls. The production of wet biomass is approximately 22,058 kilograms of wet matter over the $6 \mathrm{~m}^{2}$ during the four months of the experiment: $4 \mathrm{~kg} / \mathrm{MH} / \mathrm{m}^{2}$ and $7846 \mathrm{~kg}$ of dry matter or $1.5 \mathrm{~kg} / \mathrm{MS} / \mathrm{m}^{2}$ for the same area and for the same period.

In addition, under the same conditions, we obtained a wet and dry biomass of $18.769 \mathrm{~kg}$ or $3 \mathrm{~kg} / \mathrm{MH} / \mathrm{m}^{2}$ and $6.76 \mathrm{~kg}$ or $1 \mathrm{~kg} / \mathrm{MS} / \mathrm{m}^{2}$ respectively for the controls. Differentials of $1 \mathrm{~kg} / \mathrm{MH} / \mathrm{m}^{2}$ and $0.5 \mathrm{~kg} / \mathrm{MS} / \mathrm{m}^{2}$ are noted between wet and dry biomasses of the treated and controls, respectively. The Wilcoxon test also shows a significant difference between the two populations studied. These results 
Table 2. Physico-chimical characterizes.

\begin{tabular}{|c|c|c|c|}
\hline & \multicolumn{2}{|c|}{ Parameters } & Results \\
\hline \multirow[t]{3}{*}{ Physical characteristics } & \multicolumn{2}{|c|}{ Clay } & $27.45 \%$ \\
\hline & \multicolumn{2}{|c|}{ Silt } & $23.53 \%$ \\
\hline & \multicolumn{2}{|c|}{ Sand } & $49.02 \%$ \\
\hline \multirow{18}{*}{ Chimical elements } & \multirow{3}{*}{ Water constants (\%) } & pF 2.5 & 17.29 \\
\hline & & pF 3.0 & 12.41 \\
\hline & & $\mathrm{pF} 4.2$ & 6.26 \\
\hline & \multirow{4}{*}{ Carbon and organic matter } & Total organic matter & 1.234 \\
\hline & & Total Carbon (C) & 0.716 \\
\hline & & Total Azote (A) & 0.06 \\
\hline & & $\mathrm{C} / \mathrm{N}$ & 12 \\
\hline & Phosphorus & Available phosphorus in ppm & 16.09 \\
\hline & Potassium & Potassium available in ppm & 49.67 \\
\hline & \multirow{8}{*}{ Exchangeable bases meq/100 g } & Calcium $\left(\mathrm{Cau}^{++}\right)$ & 1.5 \\
\hline & & Magnesium $\left(\mathrm{Mgu}^{++}\right)$ & 0.42 \\
\hline & & Potassium $\left(\mathrm{Ku}^{+}\right)$ & 0.17 \\
\hline & & Sodium $\left(\mathrm{Nau}^{+}\right)$ & 0.02 \\
\hline & & Sum of bases (S) & 2.03 \\
\hline & & Exchange capacity $(\mathrm{T})$ & 3.4 \\
\hline & & Saturation level $(\mathrm{S} / \mathrm{T})$ & 60 \\
\hline & & Soil moisture & 14 \\
\hline & Soil restraint & $\mathrm{PH}$ water (W/V: 1/2.5) & 5.63 \\
\hline
\end{tabular}

Table 3. Paired wilcoxon test.

\begin{tabular}{ccc}
\hline Variable poids & A & P-value ou valeur test \\
\hline Fresh weight & & 0.01582 \\
Dry weight 1 & 0.05 & 0.01574 \\
Dry weight 2 & & 0.01977 \\
Dry weight 3 & 0.003646 \\
\hline
\end{tabular}

Source: Field Work (August 2016).

show that potassium polyacrylate can be an alternative to repeated droughts in crop production.

\section{Conflicts of Interest}

The authors declare no conflicts of interest regarding the publication of this paper. 


\section{References}

[1] Charney, J.G. (1975) Dynamics of Deserts and Drought in the Sahel. Quarterly Journal of the Royal Meteorological Society, 101, 193-202. https://doi.org/10.1002/qj.49710142802

[2] Lamb, P.J. (1982) Persistence of Sub-Saharan Drought. Nature, 299, 46-48. https://doi.org/10.1038/299046a0

[3] Le Barbé, L., Lebel, T. and Tapsoba, D. (2002) Rainfall Variability in West Africa during the Years 1950-1990. Climate, 15, 187-202. https://doi.org/10.1175/1520-0442(2002)015<0187:RVIWAD>2.0.CO;2

[4] Balme, M., Lebel, T. and Amani, A. (2010) Années sèches et années humides au Sahel: quo vadimus? Hydrological Sciences Journal, 51, 254-271.

https://doi.org/10.1623/hysj.51.2.254

[5] Bodian, A., Ndiaye, O. and Dacosta, H. (2016) Evolution des caractéristiques des pluies journalières dans le bassin versant du fleuve Sénégal: Aavant et après rupture. Hydrological Sciences Journal, 61, 905-913. https://doi.org/10.1080/02626667.2014.950584

[6] Zoungrana, B.J., Conrad, C., Amekudzi, L.K., Thiel, M. and Da, E.D. (2015) Land Use/Cover Response to Rainfall Rariability: A Comparing Analysis between NDVI and EVI in the Southwest of Burkina Faso. Climate 2015, 3, 63-77. https://doi.org/10.3390/cli3010063

[7] Lebel, T., Sauvageot, H., Hoepffner, M., Desbois, M., Guillot, B. and Hubert, P. (2009) Rainfall Estimation in the Sahel: the EPSAT-NIGER Experiment. Hydrological Sciences Journal, 37, 201-215. https://doi.org/10.1080/02626669209492582

[8] Ouoba, P.A., Da, D.E.C. and Paré, S. (2014) Effet de la variabilité climatique et des activités anthropiques sur la dynamique de l'occupation des terres à Gandafabou dans le Sahel burkinabé. Cahiers Du CBRST, 6, 68-94.

[9] Barra, T.S., Neto Dantas, F.S. and Costa, J.M.N. (1965) Climatological Analysis of the Droughts in Jaguaribe Region. Ceará State, Brazil.

[10] Balme, M., Galle, S. and Lebel, T. (2005) Démarrage de la saison des pluies au Sahel: variabilité aux échelles hydrologique et agronomique, analysée à partir des données EPSAT-Niger. Sécheresse, 16, 15-22.

[11] Afouda, A. and Adisso, P. (1997) Etude stochastique des structures de séquences sèches au Bénin. Sustainability of Water Resources under Increasing Uncertainy, 153-162.

[12] Palé, S. and Da, D.E.C. (2016) Traditional Lowlands Water Management in Dano, South-Western Burkina Faso. Journal of Water Resource and Protection. http://www.scirp.org/journal/jwarp https://doi.org/10.4236/jwarp.2016.84035

[13] Pittock, J. and Dovers, S. (2009) Why a Special Issue on Adaptation and Water Management? Climate and Development, 1, 191-193.

https://doi.org/10.3763/cdev.2009.0019

[14] Da, D.E.C., Yacouba, H. and Yonkeu, S. (2008) Unités morphopédologiques et gestion de la fertilité des sols dans le Centre-Nord du Burkina Faso par les populations locales. International Journal of Biological and Chemical Sciences, 2, 306-315. https://doi.org/10.4314/ijbcs.v2i3.39746

[15] Gómez J. S. (2015) Characterization and Effects of Cross-Linked Potassium Polyacrylate as Soil Amendment. Universitad de Sevilla.

[16] Garía, I.E., Bali, K.M., Márquez, A.P. and Calleros, J.R. (2014) Effect of the Use of Potassium Polyacrylate Clay Soils for Optimization of Irrigation Water in the Valley 
of Maxicali, Baja California, Mexico. International Journal of Current Research, 6, 2015-2017.

[17] Amani, A., Lebel, T. and Litzer, Q. (2002) Optimisation des réseaux pluviométriques nationaux des pays membres du CILSS.

[18] Burch, S. and Robinson, J. (2007) A Framework for Explaining the Links between Capacity and Action in Response to Global Climate Change. Climate Policy, 7, 304-316.

[19] Dubief, J. (1965) Le climat du Sahara. Annales de Géographie, 74, 360-361.

[20] Faye, C. (2019) Quantification de la sécheresse météorologique par des indices standardisés de précipitations dans la vallée du fleuve Sénégal de 1980 à 2017. Revue de géographie du Laboratoire Leïdi, 21, 108-122.

[21] Filippi, C., Milville, F. and Thiery, D. (1990) Evaluation de la recharge naturelle des aquifères en climat Soudano-Sahelien par modelisation hydrologique globale: Application a dix sites au Burkina Faso. Hydrological Sciences Journal, 35, 29-48.

[22] Nicholson, S.E., Ba, M.B. and Kim, J.M. (1996) Rainfall in the Sahel during 1994. Journal of Climate, 9, 1673-1676. 